\title{
Plant species diversity of some wadis at Red Sea Coast, Egypt
}

\author{
Ahmed A. El-Khouly, A and Ramadan A. Shawky \\ Plant Ecology and Ranges Department, Desert Research Center, El-Matariya, Cairo, Egypt. \\ Email: ramadan_salam@hotmail.com
}

Keywords: Red Sea, Floristic Diversity, Wadi El-Mallaha and W. Esli, Egypt.

\begin{abstract}
The present study aims to investigate the variation in vegetation and species diversity in two coastal wadis (Wadi El-Mallaha and W. Esli) which drain their water from surrounding high mountains into the Red Sea. It attempted to compare the floristic diversity between these wadis to recognize the different distribution patterns of species, and to assess the role of the edaphic factors which control the distribution of the plant communities. Fourteen sample plots were selected to represent as much as possible the variation in the vegetation, and georeferenced using GPS techniques. A total of 23 perennial species belonging to 19 genera and 14 families were recorded, with Zygophyllaceae, Fabaceae, Tamaricaceae and Asteraceae represented the species-rich families. Phanerophytes and Chamaephytes constituted the main bulk of the flora, followed by hemicryptophytes. As part of the Saharo-Arabian region, the Saharo-Arabian chorotype dominated the others. Classification of the vegetation resulted in 6 vegetation groups: (A) Juncus rigidus, (B) Zygophyllum coccinium, (C) Capparis decidua, (D) Zilla spinosa, (E) Zygophyllum coccinium and (F) Nitraria retusa. Species richness was Positively correlated with fine gravel, while negatively correlated with medium sand. The Shannon's diversity and Simpson Indices showed positive correlation with $\mathrm{CaCO}_{3}$ and negative correlation with fine sand. Vegetation-soil relationships were assessed by Canonical Correspondence Analysis (CCA) using 18 soil factors indicated that gravel, coarse sand, fine sand, silt, clay, sodium and chlorides were the key soil variables that affect the distribution of plant communities in the coastal wadis of Red Sea region.
\end{abstract}

\section{Introduction}

The vegetation in Egypt's deserts is by far the most important and characteristic type of natural plant life. It covers about $95 \%$ of the total area of the country, and is mainly formed of xerophytic shrubs and sub-shrubs. [1] Monod recognized two types of desert vegetation, namely contracted and diffuse. Both types refer to permanent vegetation that can be accompanied by ephemeral (or annual) plant growth depending on the amount of precipitation in a given year. [2; 3] Kassas added a third type termed "accidental vegetation", where precipitation is very low and falls so irregularly that no permanent vegetation exists. The most critical gradients in abiotic factors may be related to water availability, including annual precipitation, topography and soil properties [4].

The wadis are unique intrazonal landscapes in arid and semi-arid regions of the world [5], as 
they represent one of the most prominent desert landforms, which exhibit physiographic irregularities that lead to parallel variations in species distribution [6]. These wadis are drainage systems for collecting water from extensive catchments areas such as hills, cliffs, slopes, etc. Accordingly, the water supply of a wadi is many times the recorded rainfall; with richer vegetation than other types of desert habitat. This advantage is, however, counterbalanced by two destructive agents: torrents and grazing. The water way of the torrents is usually devoid of plant cover, which is restricted to the wadi sides. The influence of torrents on plants is partly mechanical, destroying and uprooting the plants, and partly erosion removing the soil [7]. In addition, certain species are subjected to serious grazing by animals, while woody plants are liable for cutting as a source of fuel.

Several studies on the desert wadi ecosystem were conducted in arid and semi-arid regions to investigate their floristic composition, relationships between the prevailing environmental conditions and the distribution of plant communities, economic and grazing potentialities, amongst others, in Wadi Araba of Jordan [8]; in Wadi Al-Hayat of Libya [9]; in Wadi Al Jimi of United Arab Emirates [10]; in Wadi Al-Jufair (Najd) of Saudi Arabia [11]; in Wadi Noaman (Makkah) of Saudi Arabia [12]; in Wadi Gaza (Gaza Strip) of Palestine [13]; in different wadi types from Ahaggar region of Algeria [14].

The objectives of this investigation are: (1) comparing the floristic composition and species diversity between two studied wadis of The Egyptian Eastern desert; (2) recognizing the different plant communities that dominate the vegetation in the studied Wadis; and (3) assessing the role of the edaphic factors which control the distribution of the plant communities and species diversity.

\section{Study area}

The Eastern Desert of Egypt occupies the area extending from the Nile Valley eastward to the Gulf of Suez and the Red Sea, which is about 223,000 km2, i.e. $21 \%$ of the total area of Egypt. On the other hand, the studied wadis is located north Hurghada (Wadi El-Mallaha) and south ElQussier (Wadi Esli) which extend eastward to the Red Sea Coast (Figure 1). These two localities represent the natural xeric habitat which is mainly inhabited by xerophytic vegetation.

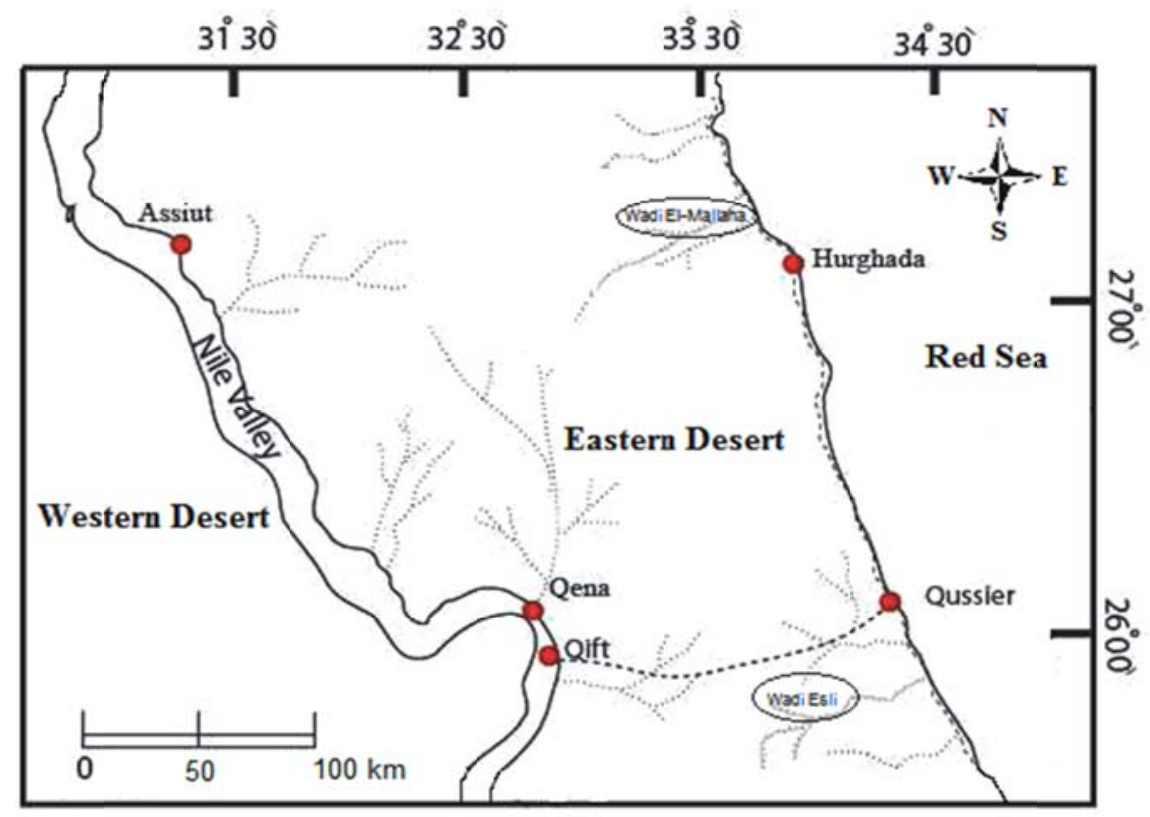

Figure 1: Location map showing the studied wadis.

Climatically, the study area lies within the hyperarid provinces [15] with a mild winter and a hot 
summer (mean temperature of the hottest month $20-30^{\circ} \mathrm{C}$ ). The mean annual rainfall ranges from $25 \mathrm{~mm}$ in Suez, $4 \mathrm{~mm}$ in Hurghada to $3.4 \mathrm{~mm}$ in El-Qusseir and $1.2 \mathrm{~mm}$ in Mersa Alam. On daily basis, the mean minimum temperature is high and ranges between 18 and $22.3^{\circ} \mathrm{C}$ in and mean maximum $27.8-29.5^{\circ} \mathrm{C}$. Relative humidity ranges from $46.1 \%$ in Hurghada to $54.4 \%$ in Mersa Alam. The wind velocity ranges between 9.55 in Mersa Alam and 11.7 in El-Quseir. Some climatic features in certain stations along the Red Sea coast and the Nile Valley may explain environmental aridity and thermal continentality which increases from north to south (Table 1).

Table 1: Annual average (over 50 years) of some climatic features at Four meteorological stations within the study area. (Max=maximum, Min= Minimum). according to Climatic Normal of Egypt.

\begin{tabular}{|c|c|c|c|c|c|}
\hline \multirow{2}{*}{ Station } & \multicolumn{2}{|c|}{ Temperature $\left({ }^{\circ} \mathbf{C}\right)$} & \multirow{2}{*}{ Rainfall (mm) } & $\begin{array}{c}\text { Relative } \\
\text { humidity } \mathbf{( \% )}\end{array}$ & $\begin{array}{c}\text { Wind Velocity } \\
(\mathbf{k m} / \mathbf{h})\end{array}$ \\
\cline { 2 - 3 } & $\mathbf{M a x}$ & Min & & 53.1 & 11.6 \\
\hline Suez & 28.1 & 18.0 & 25.0 & 46.1 & 10.1 \\
\hline Hurghada & 27.8 & 18.6 & 4.0 & 49.8 & 11.7 \\
\hline EI-Quseir & 28.0 & 18.7 & 3.4 & 54.4 & 9.55 \\
\hline Mersa Alam & 29.5 & 22.3 & 1.2 & \multicolumn{2}{|c|}{} \\
\hline
\end{tabular}

\section{Materials and Methods}

\subsection{Vegetation survey}

Vegetation survey and assessing the ecological situation of plants were carried out in the summer season of the year 2016 at two studied wadis namely Wadi El-Mallaha and Wadi Esli. fourteen stands ( 7 stand, each) have been selected for sampling vegetation. These stands were randomly chosen at locations where considerable vegetation cover was encountered. The density and cover of each species have been estimated in each selected stand [16]. Relative values of density and cover were calculated for each plant species and summed up to give an estimate of its important value (IV) in each stand which is out of 30. In this extreme arid desert environment, where the vegetation comprised only of widely spaced shrubs and trees, the size of studied sample plots was $10 \mathrm{~m} \times 10 \mathrm{~m}$. The recorded taxa were classified according to the life-form system that proposed by $[17 ; 18]$. The number of species within each life form category was expressed as a percentage of total number of species in the study area. Analysis of phytogeographical ranges was carried out using $[19 ; 20 ; 21]$. Taxonomic nomenclature was according to $[22 ; 23 ; 24]$.

\subsection{Soil analysis}

For each sampled stand, three soil samples were collected from profiles of 0-40 cm depth. These samples were then pooled together to form one composite sample, air dried and thoroughly mixed. Textures were determined by sieving method to separate gravels, coarse sand, fine sand, silt and clay for physical and chemical analyses [25]. Soil-water extracts (1:5) were prepared for the determination of electric conductivity and $\mathrm{pH}$. Determination of calcium and magnesium were carried out by titration methods with $0.01 \mathrm{~N}$ EDTA [26]. Sodium and potassium were determined using flame photometer technique [27]. Estimation of chlorides was carried out by titration methods using $0.005 \mathrm{~N}$ Silver Nitrate [28; 29].

\subsection{Data analyses}

A floristic data matrix of 14 stands and 23 species was subjected for classification by two way indicator species analysis (TWINSPAN, version 2.3) [30]. The relation between the vegetation and soil gradients was assessed using the appropriate ordination method to perform direct gradient analysis Canonical Correspondence Analysis (CCA) [31]. Plant diversity indices included species richness (SR), Shannon-Weiner diversity index $\left(\mathrm{H}^{\prime}\right)$ and Simpson index. These diversity indices 
were estimated for each vegetation group [32; 33; 34]. Taxonomic diversity including species/genera and genera/families ratios for studied area as a whole was determined [35]. The obtained data were statistically evaluated using COSTAT 6.4 for Windows.

\section{Results}

\subsection{Floristic analysis}

Table 2: Floristic composition of the recorded species in studied region. $\mathrm{P} \%=$ presence value, $\mathrm{Ph}=$ Phanerophyte, $\mathrm{H}=$ Hemicryptophyte, $\mathrm{Ch}=$ Chemaephyte, $\mathrm{M}=$ Mediterranean, $\mathrm{SA}=$ Saharo-Arabian, $\mathrm{SZ}=$ Sudano-Zambezian and IT= Irano-Turanian.

\begin{tabular}{|c|c|c|c|}
\hline Species & Chorotype & Life form & $\mathbf{P} \%$ \\
\hline \multicolumn{4}{|l|}{ Amaranthaceae } \\
\hline Aerva javanica (Burm.F.) Juss. ex. Schult. & SA-SZ & $\mathrm{Ch}$ & 7.14 \\
\hline \multicolumn{4}{|l|}{ Arecaceae } \\
\hline Phoenix dactylifera $\mathrm{L}$. & SA & $\mathrm{Ph}$ & 14.3 \\
\hline \multicolumn{4}{|l|}{ Asclepiadaceae } \\
\hline Leptadenia pyroyechnica (Forrsk.) Decne. & SA & $\mathrm{Ph}$ & 7.14 \\
\hline \multicolumn{4}{|l|}{ Asteraceae } \\
\hline Achellia fragrentisma (Forssk.) Sch.Bip. & M-SA-IT & $\mathrm{Ch}$ & 14.3 \\
\hline Pulicaria undulata (L.) C. A. Mey & SA & $\mathrm{Ch}$ & 7.14 \\
\hline \multicolumn{4}{|l|}{ Brassicaceae } \\
\hline Zilla spinosa Forssk. & SA & $\mathrm{Ch}$ & 71.4 \\
\hline \multicolumn{4}{|l|}{ Capparaceae } \\
\hline Capparis decidua (Forssk.) Edgew. & M-SA-IT & $\mathrm{Ch}$ & 14.3 \\
\hline \multicolumn{4}{|l|}{ Cleomaceae } \\
\hline Cleome dreserifolia (Forssk.) Delile. & SA-IT & $\mathrm{H}$ & 7.14 \\
\hline \multicolumn{4}{|l|}{ Fabaceae } \\
\hline Acacia tortilis subsp. raddiana Savi & SA-SZ & $\mathrm{Ph}$ & 35.7 \\
\hline Acacia tortilis (Forssk.) Hayne. subsp. tortilis & SA-SZ & $\mathrm{Ph}$ & 7.14 \\
\hline Alhagi graecourum Boiss. & M-IT & $\mathrm{H}$ & 7.14 \\
\hline \multicolumn{4}{|l|}{ Juncaceae } \\
\hline Juncus rigidus (Desf.) Fl. Atlant. & M-IT & $\mathrm{H}$ & 14.3 \\
\hline \multicolumn{4}{|l|}{ Nitrariaceae } \\
\hline Nitraria retusa (Forssk.) Ach. & SA & $\mathrm{Ph}$ & 21.4 \\
\hline \multicolumn{4}{|l|}{ Poaceae } \\
\hline Aeluropus lagopoides (L.) Trin. & SA & $\mathrm{Ch}$ & 7.14 \\
\hline Phragmites australis (Cav.) Trin. ex Steud & M-SA-IT & $\mathrm{H}$ & 14.3 \\
\hline \multicolumn{4}{|l|}{ Tamaricaceae } \\
\hline Tamarix mannefera (Ehrenb.) ex Bunge & SA & $\mathrm{Ph}$ & 14.3 \\
\hline Tamarix nilotica $\mathrm{L}$. & SA & $\mathrm{Ph}$ & 21.4 \\
\hline Tamarix passerinoides Delile. & SA & $\mathrm{Ph}$ & 7.14 \\
\hline \multicolumn{4}{|l|}{ Urticaceae } \\
\hline Forsskaolea tenacissima L. & SA-SZ & $\mathrm{H}$ & 7.14 \\
\hline \multicolumn{4}{|l|}{ Zygophyllaceae } \\
\hline Balanites aegyptiaca L. & SA & $\mathrm{Ph}$ & 7.14 \\
\hline Fagonia arabica L. & SA & $\mathrm{Ch}$ & 14.3 \\
\hline Zygophyllum album L. & M-SA & $\mathrm{Ch}$ & 7.14 \\
\hline Zygophyllum coccinium L. & M-SA & $\mathrm{Ch}$ & 100 \\
\hline
\end{tabular}


The floristic diversity of study area showed that a total of 23 species belonging to 19 genera and 14 families were recorded (Table 2). The species/genera ratio is $1.21 \%$ and genera/families ratio is $1.3 \%$. Generally, The largest family was Zygophyllaceae (4 species), Fabaceae and Tamaricaceae (3 species, each) and Asteraceae (2 species). They constituted $52.2 \%$ of the recorded species, and represent most of the floristic structure in the studied wadis. Nine families were represented by only one species. The largest genera were Tamarix ( 3 species) and Zygophyllum and Acacia (2 species, each). Phanerophytes and Chamaephytes (39.1\%, each) constituted the largest number of species (9 species each) and hemicryptophytes (21.7\%). Obviously, genus with higher number of species included Tamarix (3 species). Another nine genera were represented by two species, including, Acacia and Zygophyllum.

Chorological analysis of the surveyed flora revealed that 11 species (47.8\% of the total flora) were monoregional native to Saharo-Arabian chorotype. Thus it forms the major component of the floristic composition of this study (Table 2). About 39.1\% of the recorded species were biregional and pluriregional extending their distribution all over the Mediterranean, Saharo-Arabian, IranoTuranian regions. Being part of Saharo-Arabian region, the Saharo-Arabian chorotype (Mono-; biand pluri-) constitutes $47.8 \%$ and $30.4 \%$ and $13 \%$ of the recorded species, respectively.

Table 3: Comparison between the floristic compositions in the 2 studied wadis (Figures are the presence percentages of species).

\begin{tabular}{|c|c|c|}
\hline Species & Wadi Esli & $\begin{array}{l}\text { Wadi El- } \\
\text { Mallaha }\end{array}$ \\
\hline \multicolumn{3}{|l|}{ Species present in two studied wadis } \\
\hline Acacia tortilis subsp. raddiana Savi & 42.9 & 28.6 \\
\hline Achellia fragrentisma (Forssk.)Sch.Bip. & 14.3 & 14.3 \\
\hline Nitraria retusa (Forssk.) Ach. & 28.6 & 14.3 \\
\hline Zilla spinosa Forssk. & 71.4 & 71.4 \\
\hline Zygophyllum coccinium L. & 100 & 100 \\
\hline \multicolumn{3}{|l|}{ Species present in one wadi } \\
\hline Acacia tortilis (Forssk.) Hayne. subsp. tortilis & 14.3 & 0 \\
\hline Aeluropus lagopoides (L.) Trin. & 14.3 & 0 \\
\hline Aerva javanica (Burm.F.) Juss. ex. Schult. & 14.3 & 0 \\
\hline Alhagi graecourum Boiss. & 14.3 & 0 \\
\hline Balanites aegyptiaca L. & 0 & 14.3 \\
\hline Capparis decidua (Forssk.) Edgew. & 0 & 28.6 \\
\hline Cleome dreserifolia (Forssk.) Delile. & 14.3 & 0 \\
\hline Fagonia arabica L. & 28.6 & 0 \\
\hline Forsskaolea tenacissima L. & 14.3 & 0 \\
\hline Juncus rigidus (Desf.) Fl. Atlant. & 28.6 & 0 \\
\hline Leptadenia pyroyechnica (Forrsk.) Decne. & 0 & 14.3 \\
\hline Phoenix dactylifera L. & 28.6 & 0 \\
\hline Phragmites australis (Cav.) Trin. ex Steud & 28.6 & 0 \\
\hline Pulicaria undulata (L.) C. A. Mey & 0 & 14.3 \\
\hline Tamarix mannefera (Ehrenb.) ex Bunge & 0 & 28.6 \\
\hline Tamarix nilotica L. & 42.9 & 0 \\
\hline Tamarix passerinoides Delile. & 14.3 & 0 \\
\hline Zygophyllum album L. & 0 & 14.3 \\
\hline
\end{tabular}

The two studied wadis shared 5 species or about $21.7 \%$ of the total recorded species (23) (Table 
3). Among the recorded species Acacia tortilis subsp. raddiana, Achellia fragrentisma, Nitraria retusa, Zilla spinosa and Zygophyllum coccinium. Eighteen species showed a degree of consistency to a certain wadi, and distributed as follows: 12 species to Wadi Esli and 6 species to Wadi ElMallaha (Table 3). Three ubiquitous (have a wide ecological range of distribution) were recorded: Zygophyllum coccinium, Zilla spinosa and Acacia tortilis subsp. raddiana have the highest presence values $(\mathrm{P}=100 \%, 71.4 \%$ and $35.7 \%$, respectively $)$. On the other hand, the annuals are absent, demonstrated a certain degree of constancy.

\subsection{Classification of vegetation}

Application of classification using cluster analysis to the floristic data of the studied wadis yielded 6 vegetation groups (Figure 2). Zygophyllum coccinium is recorded with variable presence values in all the 6 groups (Table 2). Significant differences in the examined soil variables within the separated vegetation groups were demonstrated in (Table 4), such as Moisture, Electric conductivity and chlorides showed clear significant differences between groups at $p<0.05$.

\section{Group (A): Juncus rigidus group}

The 8 species in this group were recorded in two stands with average species richness of $4.00 \pm 0.00$ species per sample plot, Shannon-Wiener diversity index of $1.29 \pm 0.14$ and Simpson index of $0.41 \pm 0.04$ (Table 4). Stands of this group were found on soil rich in its electric conductivity, fine sand, moisture contents, $\mathrm{Na}, \mathrm{Cl}$ and $\mathrm{Mg}$. the abundant species was Juncus rigidus $(\mathrm{IV}=140.4)$ and the associated species were Phoenix dactylifera, Alhagi graecourum, Nitraria retusa, Aeluropus lagopoides, Phragmites australis, Tamarix nilotica and Zygophyllum coccinium (Table 5).

\section{Group (B): Zygophyllum coccineum group}

The size of this group was represented by 2 stands that included 4 species. The average species richness in this group is $2.50 \pm 0.71$ species/stands, Simpson index $0.22 \pm 0.02$ and Shannon-Wiener diversity index of $0.67 \pm 0.070$. The stands of this group inhabited soil with the highest content of potassium, coarse and medium sand (Table 4). Sporadic species included 4 species, of which Zilla spinosa, Tamarix nilotica, Balanites aegyptiaca and Zygophyllum coccinium were included (Table 5). The abundant species include Zygophyllum coccinium (IV=115.9).

\section{Group (C): Capparis decidua group}

The 5 species in this group were recorded from 3 stands, with average species richness of $3.33 \pm 0.58$ species per sample plot, Shannon diversity index of $1.07 \pm 0.2$ and Simpson index $0.34 \pm 0.07$. The stands of this group were found on soil with high content of gravel and fine gravel, and lowest contents of Silt, sodium, potassium, chlorides and calcium carbonates (Table 5). Five sporadic species were recorded that included amongst others, Pulicaria undulata, Zilla spinosa, Capparis decidua, Leptadenia pyrotechnica and Zygophyllum coccinium (Table 2). The abundant species was Capparis decidua (IV=107.9).

\section{Group (D): Artemisia judaica group}

This group comprised 7 species recorded from 1 stand, it is the most diversified group with an average species richness of 5.00 species per sample plot, Shannon-wiener diversity index of 1.80 and Simpson index 0.57 (Table 5). The stands of this group characterized by soil with the highest coarse sand and calcium, the lowest contents of fine sand, moisture content, $\mathrm{pH}$, electric conductivity, chlorides. The low number of studied stands in this group was due to rugged topography and limited accessibility. (Table 2). The abundant species was Zilla spinosa $(\mathrm{IV}=72.1)$. the associated species were Aerva javanica, Achellia fragrentisma, Cleome dreserifolia, Forsskaolea tenacissima, Fagonia arabica and Zygophyllum coccinium.

\section{Group (E): Zygophyllum coccineum group}

The size of this group was represented by 4 stands that included 7 species. The average species 
richness in this group is $4.00 \pm 1.15$ species/stands, Simpson index $0.37 \pm 0.05$ and Shannon-Wiener diversity index of $1.15 \pm 0.17$. The stands of this group inhabited soil with the highest content of sulphate and Organiv matter (Table 4). Sporadic species included 7 species, of which Achellia fragrentisma, Zilla spinosa, Acacia tortilis subsp. raddiana, Acacia tortilis, Tamarix mannefera, Fagonia arabica and Zygophyllum coccinium were included (Table 5). The abundant species include Zygophyllum coccinium (IV = 121.9).

\section{Group (F): Nitraria retusa group}

This group was represented by 3 stands that included 7 species. The average species richness in this group is $4.50 \pm 0.71$ species/stands, Simpson index $0.33 \pm 0.04$ and Shannon-Wiener diversity index of $1.08 \pm 0.13$. The stands of this group inhabited soil with the highest content of silt, clay and $\mathrm{CaCO}_{3}$ (Table 4). Sporadic species included 7 species, of which Zilla spinosa, Acacia tortilis subsp. raddiana, Nitraria retusa, Tamarix mannefera, Tamarix passerinoides, Zygophyllum album and Zygophyllum coccinium were included (Table 5). The abundant species include Nitraria retusa (IV $=138.0$ ).

Table 4: Mean values, standard deviations $( \pm)$ and ANOVA values of the soil variables in the vegetation groups (A-E) of the inland wadis.

$\mathrm{EC}=$ Electric conductivity, TSS $=$ Total soluble salts, $\mathrm{G}=$ Gravel, $\mathrm{FG}=$ Fine gravel, $\mathrm{CS}=$ Coarse sand, $\mathrm{MS}=$ Medium sand, $\mathrm{FS}=$ Fine sand, $\mathrm{SR}=$ Species richness, $\mathrm{H}=$ Shannon-Wiener index and $\mathrm{S}=$ Simpson index.

\begin{tabular}{|c|c|c|c|c|c|c|c|c|c|}
\hline \multirow{2}{*}{\multicolumn{2}{|c|}{ Soil variable }} & \multicolumn{6}{|c|}{ Vegetation groups } & \multirow{3}{*}{$\begin{array}{c}\mathbf{L S D}_{\mathbf{0 . 0 5}} \\
5.16\end{array}$} & \multirow{3}{*}{$\begin{array}{c}\text { P value } \\
0.79 \mathrm{~ns}\end{array}$} \\
\hline & & \multirow{2}{*}{$\frac{\mathbf{A}}{29.6 \pm 10.1}$} & \multirow{2}{*}{$\begin{array}{c}\text { B } \\
20.7 \pm 13.3\end{array}$} & \multirow{2}{*}{$\begin{array}{c}\mathbf{C} \\
33.2 \pm 25.4\end{array}$} & \multirow{2}{*}{$\frac{\text { D }}{12.3}$} & \multirow{2}{*}{$\frac{\mathbf{E}}{25.3 \pm 26.7}$} & \multirow{2}{*}{$\begin{array}{c}\mathbf{F} \\
22.9 \pm 10.2\end{array}$} & & \\
\hline G & \multirow{8}{*}{$\%$} & & & & & & & & \\
\hline FG & & $13.9 \pm 0.99$ & $11.6 \pm 6.29$ & $14.1 \pm 4.52$ & 1.80 & $13.8 \pm 2.30$ & $16.2 \pm 0.28$ & 9.64 & $0.68 \mathrm{~ns}$ \\
\hline CS & & $18.9 \pm 4.45$ & $26.9 \pm 9.54$ & $22.9 \pm 17.8$ & 40.1 & $24.9 \pm 17.0$ & $18.7 \pm 2.19$ & 16.2 & $0.25 \mathrm{~ns}$ \\
\hline MS & & $24.5 \pm 4.52$ & $28.9 \pm 1.90$ & $20.9 \pm 16.3$ & 25.3 & $21.8 \pm 12.1$ & $26.9 \pm 0.91$ & 18.7 & $0.89 \mathrm{~ns}$ \\
\hline FS & & $9.2 \pm 0.42$ & $7.35 \pm 4.59$ & $5.77 \pm 2.86$ & 4.2 & $8.9 \pm 5.52$ & $8.7 \pm 6.5$ & 11.6 & $0.65 \mathrm{~ns}$ \\
\hline Silt & & $1.55 \pm 1.06$ & $1.55 \pm 1.20$ & $0.83 \pm 0.35$ & 0.05 & $1.73 \pm 1.35$ & $2.05 \pm 1.90$ & 2.62 & $0.54 \mathrm{~ns}$ \\
\hline Clay & & $2.30 \pm 0.71$ & $3.0 \pm 2.4$ & $2.30 \pm 2.09$ & 0.05 & $3.73 \pm 2.56$ & $4.6 \pm 4.6$ & 6.07 & $0.57 \mathrm{~ns}$ \\
\hline Moisture & & $6.65 \pm 1.02$ & $1.12 \pm 1.10$ & $2.55 \pm 3.59$ & 1.18 & $1.23 \pm 0.91$ & $1.05 \pm 0.99$ & 4.73 & $0.11 * *$ \\
\hline \multicolumn{2}{|l|}{ pH } & $7.68 \pm 1.06$ & $7.67 \pm 1.08$ & $8.0 \pm 0.45$ & 7.51 & $7.94 \pm 0.27$ & $8.04 \pm 0.51$ & 1.66 & $0.91 \mathrm{~ns}$ \\
\hline \multicolumn{2}{|c|}{$\mathrm{EC}\left(\mathrm{mScm}^{-1}\right)$} & $22 \pm 7.70$ & $10.5 \pm 13.3$ & $13.6 \pm 21.6$ & 6.55 & $10.1 \pm 12.9$ & $7.8 \pm 9.47$ & 32.0 & $0.06 * *$ \\
\hline $\mathrm{Na}^{+}$ & \multirow{8}{*}{ T્0 } & $111.2 \pm 178$ & $90.9 \pm 116.2$ & $21.5 \pm 6.42$ & 40.8 & $110.6 \pm 132.5$ & $64.9 \pm 67.7$ & 23.2 & $0.07 * *$ \\
\hline $\mathbf{K}^{+}$ & & $2.54 \pm 2.94$ & $1.92 \pm 1.11$ & $1.33 \pm 1.53$ & 4.36 & $1.86 \pm 2.20$ & $1.41 \pm 0.44$ & 1.73 & $0.32 \mathrm{~ns}$ \\
\hline $\mathrm{Ca}^{+2}$ & & $117.5 \pm 81.3$ & $106.7 \pm 18.7$ & $113.3 \pm 61.1$ & 180 & $90 \pm 41.6$ & $110 \pm 14.1$ & 70.1 & $0.36 \mathrm{~ns}$ \\
\hline $\mathbf{M g}^{ \pm 2}$ & & $127.5 \pm 38.8$ & $73.8 \pm 76.0$ & $106.7 \pm 11.5$ & 80 & $92.5 \pm 22.1$ & $30 \pm 14.1$ & 92.0 & $0.28 \mathrm{~ns}$ \\
\hline $\mathrm{Cl}^{-}$ & & $239.5 \pm 333$ & $125.3 \pm 167.2$ & $67 \pm 84.8$ & 30 & $203.4 \pm 346.3$ & $96.3 \pm 158.1$ & 47.6 & $0.060 * *$ \\
\hline $\mathrm{SO}_{4}^{-2}$ & & $1.57 \pm 0.28$ & $1.26 \pm 0.35$ & $1.90 \pm 0.1$ & 2.83 & $2.04 \pm 0.40$ & $1.63 \pm 0.88$ & 1.02 & $0.086 \mathrm{~ns}$ \\
\hline $\mathrm{CaCO}_{3}$ & & $12.29 \pm 5.01$ & $13.1 \pm 0.89$ & $7.97 \pm 2.17$ & 6.25 & $9.76 \pm 1.13$ & $13.6 \pm 0.33$ & 5.86 & $0.089 \mathrm{~ns}$ \\
\hline OM & & $1.17 \pm 0.04$ & $1.14 \pm 0.08$ & $1.17 \pm 0.12$ & 1.14 & $1.27 \pm 0.13$ & $1.06 \pm 0.06$ & 0.18 & $0.20 \mathrm{~ns}$ \\
\hline \multicolumn{2}{|l|}{ SR } & $4.00 \pm 0.00$ & $2.50 \pm 0.71$ & $3.33 \pm 0.58$ & 5.00 & $4.00 \pm 1.15$ & $4.50 \pm 0.71$ & 1.87 & $0.002 * *$ \\
\hline \multicolumn{2}{|l|}{$\mathbf{H}$} & $1.29 \pm 0.14$ & $0.67 \pm 0.07$ & $1.07 \pm 0.2$ & 1.80 & $1.15 \pm 0.17$ & $1.08 \pm 0.13$ & 0.37 & $0.005 * *$ \\
\hline \multicolumn{2}{|l|}{$\mathbf{S}$} & $0.41 \pm 0.04$ & $0.22 \pm 0.02$ & $0.34 \pm 0.07$ & 0.57 & $0.37 \pm 0.05$ & $0.34 \pm 0.04$ & 0.12 & $0.005 * *$ \\
\hline
\end{tabular}


Table 5: Floristic composition in the vegetation groups in the study area. Values in bold are species with highest presence values.

\begin{tabular}{|l|c|c|c|c|c|c|}
\hline \multirow{2}{*}{ Species } & \multicolumn{5}{c|}{ Vegetation groups } \\
\cline { 2 - 7 } & A & B & C & D & E & F \\
\hline Aerva javanica (Burm.F.) Juss. ex. Schult. & - & - & - & 52.6 & - & - \\
\hline Phoenix dactylifera L. & 27.7 & - & - & - & - & - \\
\hline Leptadenia pyrotechnica (Forrsk.) Decne. & - & - & 28.2 & - & - & - \\
\hline Achellia fragrentisma (Forssk.)Sch.Bip. & - & - & - & 6.1 & 2.1 & - \\
\hline Pulicaria undulata (L.) C. A. Mey & - & - & 6.8 & - & - & - \\
\hline Zilla spinosa Forssk. & - & 0.9 & 69.6 & $\mathbf{7 2 . 1}$ & 91.1 & 2.4 \\
\hline Capparis decidua (Forssk.) Edgew. & - & - & $\mathbf{1 0 7 . 9}$ & - & - & - \\
\hline Cleome dreserifolia (Forssk.) Delile. & - & - & - & 30.9 & - & - \\
\hline Acacia tortilis subsp. raddiana Savi & - & - & - & - & 65.6 & 9.0 \\
\hline Acacia tortilis (Forssk.) Hayne. subsp. tortilis & - & - & - & - & 3.1 & - \\
\hline Alhagi graecourum Boiss. & 9.6 & - & - & - & - & - \\
\hline Juncus rigidus (Desf.) Fl. Atlant. & $\mathbf{1 4 0 . 4}$ & - & - & - & - & - \\
\hline Nitraria retusa (Forssk.) Ach. & 3.1 & - & - & - & - & $\mathbf{1 3 8 . 0}$ \\
\hline Aeluropus lagopoides (L.) Trin. & 3.6 & - & - & - & - & - \\
\hline Phragmites australis (Cav.) Trin. ex Steud & 87.3 & - & - & - & - & - \\
\hline Tamarix mannefera (Ehrenb.) ex Bunge & - & - & - & - & 7.2 & 6.8 \\
\hline Tamarix nilotica L. & 11.1 & 81.4 & - & - & - & - \\
\hline Tamarix passerinoides Delile. & - & - & - & - & - & 8.9 \\
\hline Forsskaolea tenacissima L. & - & - & - & 26.3 & - & - \\
\hline Balanites aegyptiaca L. & - & 101.8 & - & - & - & - \\
\hline Fagonia arabica L. & - & - & - & 49.8 & 9.2 & - \\
\hline Zygophyllum album L. & - & - & - & - & - & 73.9 \\
\hline Zygophyllum coccinium L. & 17.4 & $\mathbf{1 1 5 . 9}$ & 87.6 & 62.2 & $\mathbf{1 2 1 . 8}$ & 61.2 \\
\hline
\end{tabular}

\subsection{Ordination of sampling plots}

Application of Principal Component Analysis (PCA) resulted in the segregation of the 6 vegetation groups that were obtained from classification, with most of their sampling plots within, along the first two axes (eigenvalues 0.14 and 0.17 for axis 1 and 2, respectively) (Figure 3). Plots of group (A) were separated along the positive ends of the PCA axis 1, while those of groups (D) and (E) were separated along its negative end. On the other hand, plots of groups (B) and (F) were separated along the positive ends of the PCA axis 2, while those of groups (C) was separated along its negative end.

\subsection{Soill-vegetation relationships}

The relationship between the vegetation and soil variables was studied using Canonical Correspondence Analysis (CCA). Figure (4) showed the CCA ordination biplot with vegetation. Groups (A-F), and the examined soil variables. It can be noted that sampling plots of groups (A) was highly correlated with conductivity, fine sand, moisture contents, $\mathrm{Na}, \mathrm{Cl}$ and $\mathrm{Mg}$. On the other hand, plots of group (B) was highly associated with potassium, coarse and medium sand. Group (C) was related to gravel and fine gravel. Group D was highly associated with coarse sand and calcium. Group E was highly correlated with sulphate and Organic matter. Group F was related to silt, clay and $\mathrm{CaCO}_{3}$. 


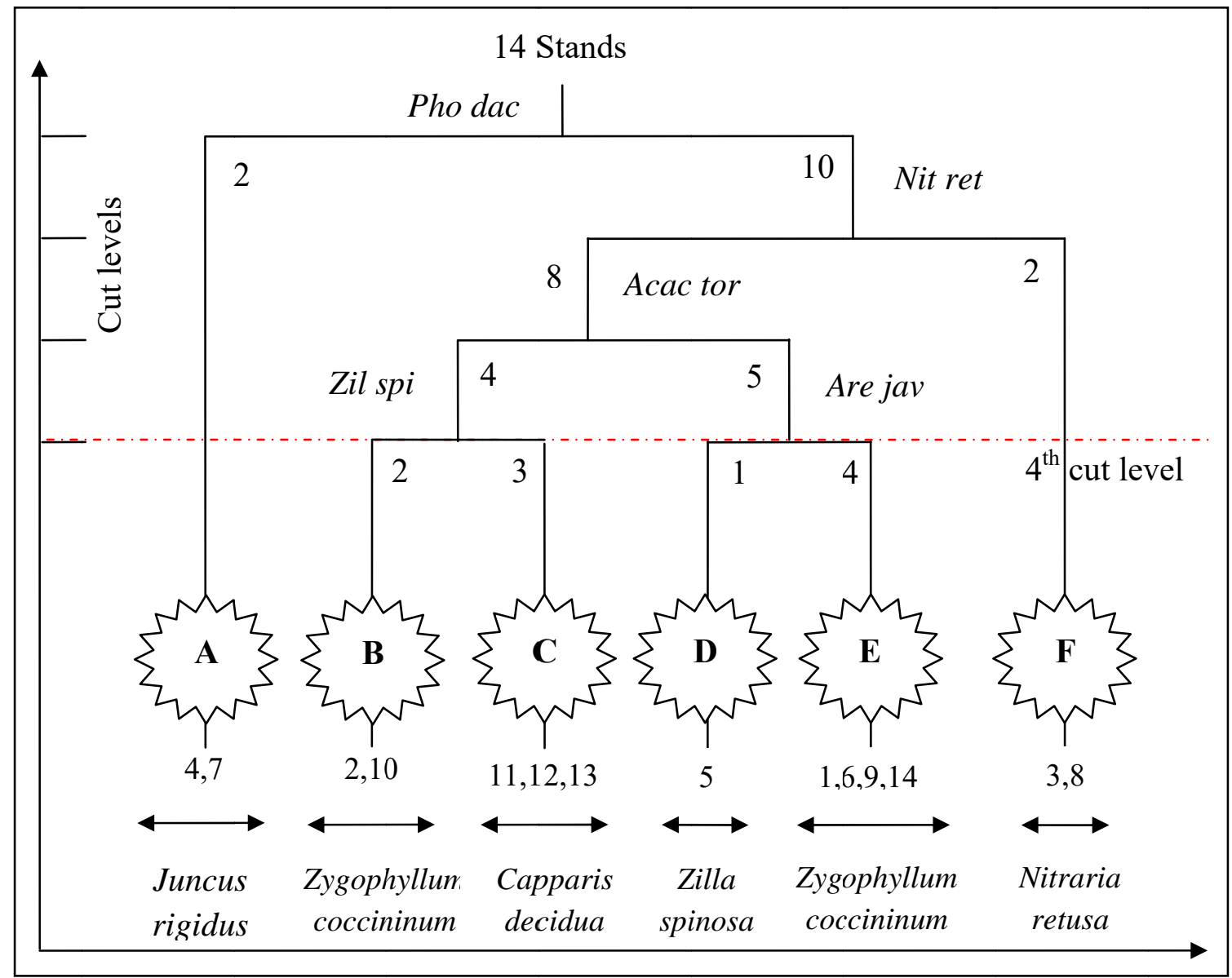

Figure 2: Dendrogram showing cluster analysis of the studied 14 sample plots of the two studied wadis, with the six vegetation groups $(\mathrm{A}-\mathrm{F})$.

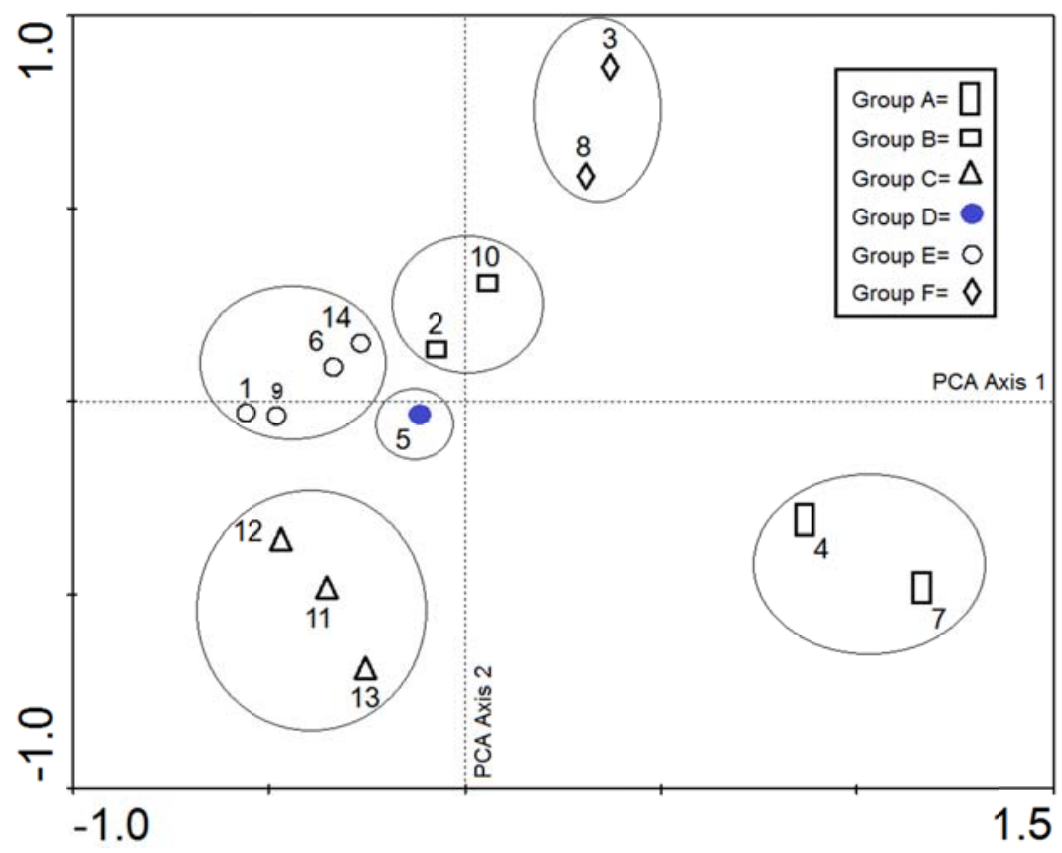

Figure 3: PCA diagram showing the distribution of the 14 sample plots of the two studied wadis within their vegetation groups 


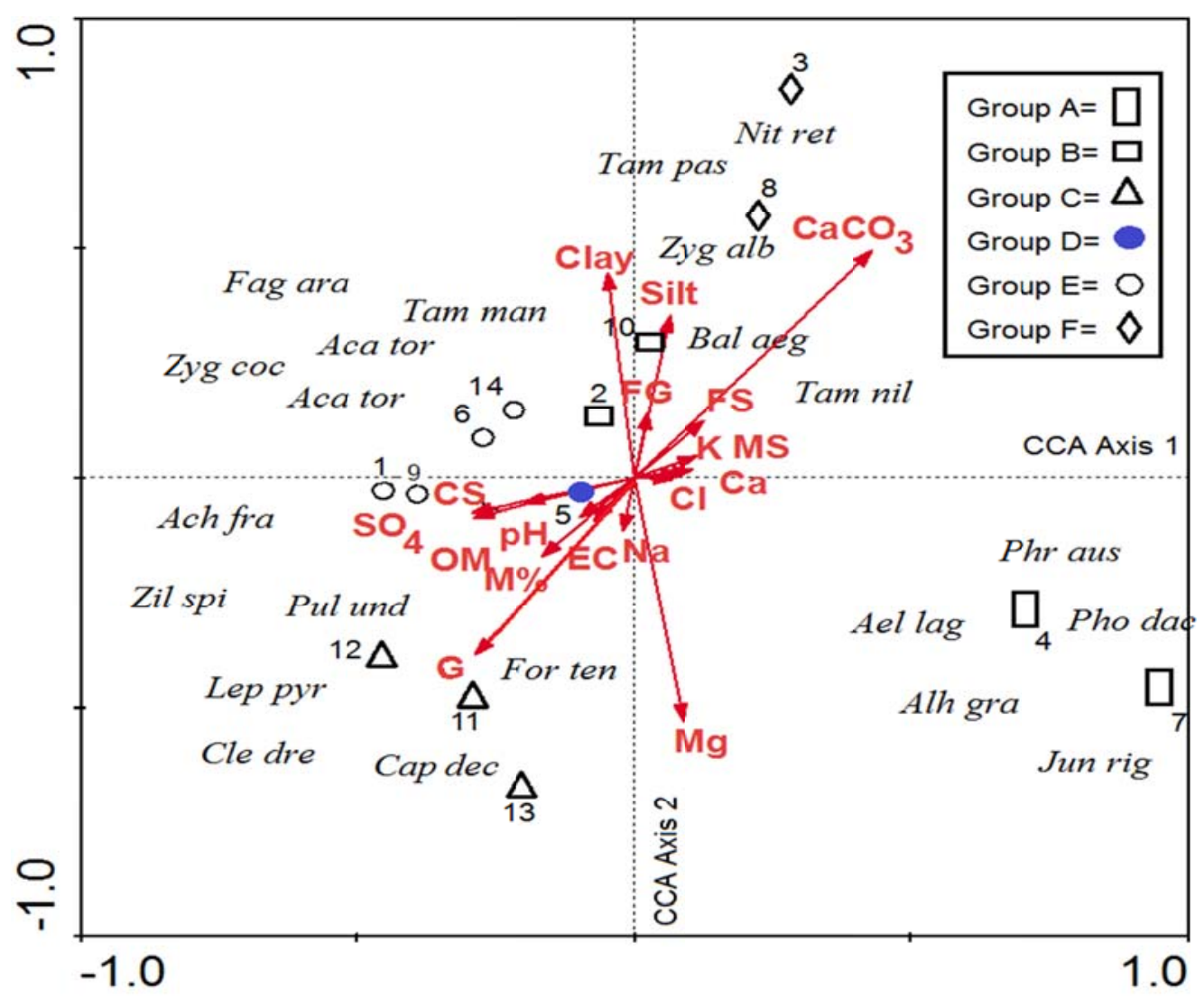

Figure 4: Canonical correspondence analysis (CCA) biplot of axes 1 and 2 showing the distribution of the 14 sample plots of the two studied wadis, together with their vegetation groups and soil variables.

The successive decrease of eigenvalues of the three CCA axes were $0.240,0.168,0.151$ and 0.137 for axes 1, 2, 3 and 4, respectively (Table 6) suggesting a well-structured data set. The species-environment correlations were higher for the fourth axis, explaining $69.5 \%$ of the cumulative variance. These results suggested an association between vegetation and the measured soil parameters presented in the biplot. CCA axis 1 was highly positively correlated with electric conductivity and highly negatively correlated gravel. So this axis can be interpreted as electric conductivity - gravel gradient. CCA axis 2 was highly positively correlated with fine sand and highly negatively with $\mathrm{pH}$. Thus, this axis can be interpreted as fine sand - $\mathrm{pH}$ gradient. $\mathrm{CCA}$ axis 3 was highly positively correlated with organic matter and highly negatively with coarse sand. Thus, this axis can be interpreted as organic matter - coarse sand gradient. CCA axis 4 was highly positively correlated with $\mathrm{CaCO}_{3}$ and highly negatively with sulphate. Thus, this axis can be interpreted as $\mathrm{CaCO}_{3}$ - sulphate gradient.

\subsection{Diversity versus soil factors}

The effects of environmental variables on species richness, Shannon's diversity index and Simpson index (Table 7) indicated that species richness was Positively correlated with fine gravel, while negatively correlated with medium sand. The Shannon's diversity and Simpson Indices showed positive correlation with $\mathrm{CaCO}_{3}$ and negative correlation with fine sand. 
Table 6: The results of ordination for the four CCA axes, intraset correlation of the soil variables, together with eigenvalues and species-environment correlation in the two studied wadis. For abbreviations and units, see Table 4.

\begin{tabular}{|c|c|c|c|c|}
\hline Axes & Ax1 & Ax 2 & $\mathbf{A x 3}$ & Ax4 \\
\hline Eigenvalues & 0.240 & 0.168 & 0.151 & 0.137 \\
\hline Species-environment correlations & 0.915 & 0.952 & 0.948 & 0.935 \\
\hline Cumulative variance & 24.0 & 40.8 & 55.8 & 69.5 \\
\hline $\mathbf{G}$ & -0.18 & -0.23 & -0.05 & -0.13 \\
\hline FG & 0.32 & 0.00 & -0.19 & -0.11 \\
\hline CS & 0.22 & 0.07 & -0.37 & 0.22 \\
\hline MS & -0.13 & 0.39 & 0.03 & -0.07 \\
\hline FS & -0.11 & 0.52 & -0.16 & -0.15 \\
\hline Silt & -0.17 & 0.43 & -0.04 & -0.27 \\
\hline Clay & 0.30 & -0.11 & -0.16 & -0.32 \\
\hline pH & -0.26 & -0.37 & 0.00 & 0.05 \\
\hline EC & 0.36 & 0.05 & -0.08 & -0.10 \\
\hline $\mathbf{N a}^{+}$ & 0.32 & 0.07 & 0.19 & 0.22 \\
\hline $\mathbf{K}^{+}$ & 0.35 & 0.08 & -0.01 & 0.09 \\
\hline $\mathbf{C a}^{+2}$ & 0.30 & -0.11 & -0.12 & 0.08 \\
\hline $\mathbf{M g}^{ \pm 2}$ & 0.12 & 0.19 & 0.52 & -0.05 \\
\hline $\mathrm{Cl}^{-}$ & 0.33 & 0.12 & 0.13 & 0.14 \\
\hline $\mathrm{SO}_{4}^{-2}$ & 0.14 & 0.00 & 0.06 & -0.64 \\
\hline $\mathrm{CaCO}_{3}$ & -0.11 & 0.31 & -0.22 & 0.44 \\
\hline OM & 0.06 & 0.02 & 0.61 & 0.12 \\
\hline
\end{tabular}

Table (7): Correlation coefficients between soil factors and diversity indices of two studied wadis.

\begin{tabular}{|c|c|c|c|}
\hline \multirow{2}{*}{$\begin{array}{c}\text { Foil } \\
\text { Factors }\end{array}$} & Species Richness & $\begin{array}{c}|c| \\
\text { Shannon's } \\
\text { diversity index }\end{array}$ & $\begin{array}{c}\text { Simpson's } \\
\text { diversity index }\end{array}$ \\
\cline { 2 - 4 } G & 0.131 & 0.157 & 0.162 \\
\hline FG & 0.290 & 0.383 & 0.375 \\
\hline $\mathbf{C S}$ & -0.111 & 0.085 & 0.085 \\
\hline $\mathbf{M S}$ & -0.206 & -0.318 & -0.320 \\
\hline $\mathbf{F S}$ & -0.016 & -0.340 & -0.344 \\
\hline Silt & 0.056 & -0.283 & -0.290 \\
\hline $\mathbf{C l a y}$ & -0.005 & -0.219 & -0.229 \\
\hline $\mathbf{p H}$ & 0.120 & 0.424 & 0.415 \\
\hline $\mathbf{E C}^{\mathbf{N}}$ & -0.121 & -0.114 & -0.105 \\
\hline $\mathbf{N a}^{+}$ & 0.016 & 0.222 & 0.216 \\
\hline $\mathbf{K}^{+}$ & -0.122 & 0.038 & 0.043 \\
\hline $\mathbf{C a}^{+2}$ & 0.173 & 0.324 & 0.321 \\
\hline $\mathbf{M g}^{+2}$ & 0.226 & 0.478 & 0.471 \\
\hline $\mathbf{C l}^{-}$ & 0.216 & 0.225 & 0.232 \\
\hline $\mathbf{S O}_{\mathbf{4}}{ }^{-2}$ & 0.071 & 0.215 & 0.216 \\
\hline $\mathbf{C a C O}_{3}$ & 0.251 & 0.511 & 0.509 \\
\hline $\mathbf{O M}^{\mathbf{2}}$ & 0.088 & -0.314 & -0.318 \\
\hline
\end{tabular}




\section{Discussion}

The desert vegetation in arid zones is relatively homogeneous but in small spatial scale is heterogeneous. Therefore, the studies of vegetation-soil relationships in these areas were usually conducted in small spatial scale $[36 ; 37 ; 38]$. The vegetation in the study area is restricted to wadis, runnels and/or depressions where runoff water collects and provides sufficient moisture for plant growth [1; 19; 39]. [2] Kassas found that the vegetation of the Red Sea wadis is characterized by sparseness of plant cover, there are limited number of plant species (mean species richness $4.5 \pm$ 1.95 on the average in studied sampling plots), The vegetation structure in the studied area is relatively simple, in which the species have to withstand the harsh environmental conditions. This is reflected to the absence of annuals and presence of several highly adapted, drought-resistant species [40].

The life form spectra provide information which may help in assessing the response of vegetation to variations in environmental factors [41]. The present study demonstrated that phanerophytes and chamaephytes constituted the largest number of species with value $(39.1 \%$, each), that agreed with those of other reports $[42 ; 43 ; 44 ; 45]$. The highest values of phanerophytes and chamaephytes may be attributed to the ability of species to resist drought, salinity, sand accumulation and over grazing, also the absence of therophytes is response to the harsh climate, topography variation and biotic influence [46].

Chorological analysis of the floristic data revealed that the Saharo- Arabian chorotype forms the major component of the floristic structure where it was represented by $47.8 \%$. This is in accordance with the results obtained in [43; 47]. This may be attributed to the fact that plants of the SaharoArabian species are good indicators for desert environmental conditions.

Spatial distribution of plant species and communities over a small geographic area in desert ecosystems is mainly related to topography and landform pattern [48]. In this context, the variations in local topography, edaphic factors and microclimatic conditions lead to the diversity of the plant communities in the study area. Classification of the vegetation resulted in 6 vegetation groups: (A) Juncus rigidus, (B) Zygophyllum coccinium, (C) Capparis decidua, (D) Zilla spinosa,(E) Zygophyllum coccinium and (F) Nitraria retusa. Most of the identified vegetation groups have similar vegetation units with that recorded in some wadis of the Eastern Desert [5;42;43;49], Western Desert [50; 51] and western Mediterranean region [52; 53], in south Sinai region [54; 55].

Several studies have provided qualitative assessments of the distribution of plant species and associations in relation to physiographic factors in different areas of the Eastern desert, In this study, soil-vegetation relationships the inland wadis revealed that gravel, coarse sand, fine sand, silt, clay, sodium and EC were the most important soil factors. This is in accordance with other relevant works in wadis of the arid and semi-arid regions. Soil texture, salinity and organic carbon can affect phytodiversity of wild communities [56;57]. These findings are also in agreement with the results obtained from this study.

\section{References}

[1] Monod, T.H. (1954). Mode contracté et diffuse de la vegetation Saharienne. In Biology of desert. (J. L. Cloudsley-Thompson, ed.), London, 35-44.

[2] Kassas, M. (1966). Plant life in deserts. In Arid Lands. (E. S. Hills, ed.), UNESCO, London, Mathuen/Paris, $145-80$.

[3] Kassas, M. (1971). Die Pflanzenwelt. 2. Teil. Pflanzenleben in der Östlichen Sahara. In Die Sahara und ihre Randgebiete. (I. Physiogeographie. (H. Sciffers, ed.), Afrika-Studien, München: Weltforum - Verlag, 477-497.

[4] Parker, K. (1991). Topography, substrate, and vegetation patterns in the northern Sonoran Desert. J. Biogeogr. 18: $151-163$.

[5] Fossati, J., Pautou, G. and Peltier, J. (1999). Water as resource and disturbance for wadi vegetation in a 
hyperarid area (Wadi Sannur, Eastern Desert, Egypt). J. Arid Environment, 4, 63-77.

[6] Kassas, M. and Girgis, W.A. (1964). Habitat and plant communities in the Egyptain desert. V: The limestone plateau. J. Ecology, 52, 107-119.

[7] Kassas, M. and El-Abyad, M.S. (1962). On the phytosociology of the desert vegetation of Egypt. Ann. Arid Zone, 1, 54-83.

[8] Jenny, M., Smettan, U. and Facklam-Moniak, M. (1990). Soil-vegetation relationship at several arid microsites in the Wadi Araba (Jordan). Vegetatio, 89, 149-164.

[9] El-Bana, M.I. and Al-Mathnani, A. (2009). Vegetation-soil relationships in the Wadi Al-Hayat Area of the Libyan Sahara. Australian J. Basic \& Applied Science, 3(2), 740-747.

[10] Mousa, M.T. (2011). Ecology and Flora of Wadi Al Jimi, Eastern Abu Dhabi Emirate, United Arab Emirates. KSU J. Natural Science, 14(2), 28-34.

[11] Alatar, A., El-Sheikh, M.A. and Thomas, J. (2012). Vegetation analysis of Wadi Al-Jufair, a hyper-arid region in Najd, Saudi Arabia. Saudi J. Biological Science, 19, 357-368.

[12] Abdel Khalik, K., El-Sheikh, M. and El-Aidarous, A. (2013). Floristic diversity and vegetation analysis of Wadi Al-Noman, Mecca, Saudi Arabia. Turkish J. Botany, 37, 894-907.

[13] Abd Rabou, A.F.N., Yassin, M.M., Al-Agha, M.R., Madi, M.I., Al-Wali, M.M., Ali A.K.S. and Hamad, D.M. (2008). Notes on some common flora and its uses in Wadi Gaza, Gaza Strip. The Islamic Univ. J. (Ser. Natural Studies and Engineering.), 16(1), 31-63.

[14] Boucheneb, N. and Benhouhou, S.S. (2012). Plant communities in the Tamanrasset region, Ahaggar, Algeria. Ecologia Mediterranea,. 38(2), 67-80.

[15] UNEP, (1992). World Atlas of Desertification. Edward Arnold, London.

[16] Canfield, R. (1941). Application of the line interception method in sampling range vegetation. J. Forestry, 39, 288-394.

[17] Raunkiaer, C. (1937). The Life Forms of Plants and Statistical Plant Geography. Clarendon Press, Oxford, $632 \mathrm{p}$.

[18] Hassib, M. (1951). Distribution of plant communities in Egypt. Bulletin of Faculty of Science. Fouad I University, 29, 59-261.

[19] Zohary, M. (1966, 1972). Flora Palaestina. Vol. 1 \& 2.The Israel Academy of Science and Humanities. Jerusalem.

[20] Wickens, G.E. (1976). The Flora of Jebel Marra (Sudan Republic) and its geographical affinities. Kew Bull. Add. Ser. 5, 5-368.

[21] White, F. (1993). The AETFAT chorological classification of Africa: history, methods and applications. Bull. Jard. Bot. Nat. Belg. 62, 225-281.

[22] Täckholm, V. (1974). Students Flora of Egypt. (2 ${ }^{\text {nd }}$ Ed.), Cairo University (Publ.) and Cooperative Printing Company, Beirut, 888 p.

[23] Boulos, L. (1999, 2001, 2002, 2005). Flora of Egypt Vol. 1-4. Al Hadara Publishing, Cairo, Egypt.

[24] Boulos, L. (2009). Flora of Egypt-Checklist $2^{\text {nd }}$ edition. Revised annotated edition. Al Hadara publisher, Cairo, Egypt, 292 p.

[25] Piper, C.S. (1947). Soil and plant analysis. Intersience Publishers. Inc. New York.

[26] Upadhyay, R.M. and Sharma, N.L. (2002). Manual of Soil, Plant, Water and Fertilizer Analysis. New Delhi, Kalyani Publishers.

[27] Jackson, M. L. (1962). Soil chemical analysis. Constable and Co. Ltd. London.

[28] Hazen, A. (1989). On determination of chloride in water. American J. Chemistry, 2, 409-425.

[29] Kolthoff, I.M. and Stenger, V.A. (1974). Volumetric Analysis. $2^{\text {nd }}$ Ed. Outfy Interscience Publishers, New York, 242-245.

[30] Hill, M.O. and Šmilauer, P. (2005). TWINSPAN for Windows version 2.3. Centre for Ecology and Hydrology; University of South Bohemia, Huntingdon and České Budějovice.

[31] Ter Braak, C.J.F. and Smilauer, p. (2002). CANOCO Reference Manual and Cano Draw for Windows User's Guide: Software for Canonical Community Ordination (version 4.5). Microcomputer power, Ithaca, New York, USA, $500 \mathrm{p}$.

[32] Whittaker, R.H. and Levin, S.A. (1977). The role mosaic phenomena in natural communities. Journal of Theoretical Population Biology, 12, 117-139.

[33] Pielou, E.C. (1975). Ecological Diversity. John Wiley and Sons, New York.

[34] Magurran, A.E. (1988). Ecological Diversity and Its Measurement. Chapman and Hall, London, 179 p.

[35] Wilson, M.Y. and Shmida, A. (1984). Measuring beta diversity with presence absence data. Journal of 
Ecology, 72, 1055-1064.

[36] Beyer L., Tielbörger K., Blume H.P., Pfisterer U., Pingpank K. and Podlech D. (1998). Geoecological soil features and the vegetation pattern in an arid dune area in the Northern Negev, Israel. Z. Pflanzenernähr. Bodenkd. 161(4), 347-356.

[37] Rietkerk, M., Ouedraogo, T., Kumar, L., Sanou, S., van Langevelde, F., Kiema, A., van de Koppel, J., van Andel, J., Hearne, J., Skidmore, A., de Ridder, N., Stroosnijder, L. and Prins, H. (2002). Fine scale spatial distribution of plant and resources on a sandy soil in the Sahel. Plant Soil, 239, 69-77.

[38] Xu, L., Liua, H., Chuc, X. and Sua, K. (2006). Desert vegetation patterns at the northern foot of Tianshan Mountains: The role of soil conditions. Flora, 201, 44-50.

[39] Walter, H. (1963). Water supply of desert plants. In: Rutter A.J. \& Whitehead E.H. (eds), The Water Relations of Plants, Blackwell, London, 199-205.

[40] Abdel-Razik, M., Abdel-Aziz, M. and Ayyad, M. (1984). Environmental gradients and species distribution in atransect at Omayed (Egypt). J. Arid Environment, 7, 337-352.

[41] Ayyad, M.A. and El-Ghareeb, R.E.M. (1982). Salt marsh vegetation of the Western Mediterranean desert of Egypt. J. Vegetatio, 49, 3-19.

[42] Salama, F.M., Ahmed, M.K., El-Tayeh, N.A. and Hammad, S.A. (2012). Vegetation analysis, phenological patterns and chorological affinities in Wadi Qena, Eastern Desert, Egypt. African Journal of Ecology, 50(2), 193-204.

[43] Salama, F.M., Abd EI-Ghani, M.M. and El-Tayeh, N. (2013). Vegetation and soil relationships in the inland wadi ecosystem of central Eastern Desert, Egypt. Turkish J. Botany, 37(3), 489-498.

[44] Salama, F.M., Sayed, S.A. and Abd El-Gelil, A (2014). Plant Communities and Floristic Composition of the Vegetation of Wadi Al-Assiuty and Wadi Habib in the Eastern Desert, Egypt. Not. Sci. Biol. 6(2):196-206.

[45] El-Amier, Y.A., El-Halawany, E.F. and Abdullah, T.J. (2014). Composition and diversity of plant communities in sand formations along the northern coast of the Nile Delta in Egypt. Research J. Pharmaceutical Biology and Chemistry Science, 5(4), 826-847.

[46] Heneidy, S.Z. and Bidak, L.M. (2001). Multipurpose plant species in Bisha, Asir region, southwestern Saudi Arabia. J. King Saud University, 13, 11-26.

[47] Danin, A. and Plitman, U. (1987). Revision of the plant geographical territories of Israel and Sinai. Plant Systematic, 156, 43-53.

[48] Kassas, M. and Batanouny, K.H. (1984). Plant Ecology. In: Cloudsley-Thompson J. J. (ed.), Sahara Desert. Pergamum Press, Oxford, 77-90.

[49] Abd El-Ghani, M. M. (1998). Environmental correlates of species distribution in arid desert ecosystems of Eastern Egypt. J. Arid Environment, 38, 297-313.

[50] Bornkamm, R. and Kehl, H. (1990). The plant communities of the western desert of Egypt. Phytocoenologia, 19, 149-231.

[51] Abd El-Ghani, M.M. (2000). Floristic and environmental relations in two extreme desert zones of western Egypt. Global Ecology and Biogeography, 9, 499-516.

[52] Kamal, S.A. and El-Kady, H.F. (1993). Vegetation analysis of some wadis in the Egyptian Mediterranean desert. Feddes Repertorum, 104(7-8), 537-545.

[53] Salama, F.M., Abd El-Ghani, M.M., El-Naggar, S.M. and Baayo, Kh. (2005). Vegetation structure and environmental gradients in the Sallum area, west Mediterranean, Egypt. Ecologia Meditanea. 31(1), 15-32.

[54] El-Ghareeb, R. and Shabana, M.A. (1990). Vegetation-environmental relationships in the bed of Wadi ElSheikh of Southern Sinai. Vegetatio, 90, 145-157.

[55] El-Kady, H., Heneidy, S. and El-Demerdash, M. (1998). Vegetation analysis of the northern Aqaba Gulf coastal land of Egypt. J. Union Arab Biology, 6(B), 319-328.

[56] Andersson, T.N. and Skovgaard, I.M. (2009). Crop and soil factors of importance for the distribution of plant species on arable fields in Denmark. Agricultural Ecosystems Environment, 133, 61-67.

[57] Pinke, G., Pal, R. and Botta-Dukat, Z. (2010). Effects of environmental factors on weed species composition of cereal and stubble fields in western Hungary. Cent. Eur. J. Biology, 5, 283-292. 